\title{
Renewable Land: Planning the Evolution of Logistic Areas
}

\author{
Carlos Alonso-Montolio ${ }^{1}$ | Gloria Serra-Coch 2 | Antonio Isalgue ${ }^{3}$ \\ Received: 2019-11-25 | Final version: 2021-06-01
}

\begin{abstract}
Land is the support of life and the generator of energy cycles in the planet, also being a finite resource. The first consequence of urban population growth and build environment expansion is land consumption. Present strategies reduce this expenditure, generally by attenuating dispersive growth, favouring compact city models and reusing built inventory. From current urban land, a noteworthy percentage is assigned for logistic use and this proportion is increasing as a consequence of delocalized economies. However, planning strategies seem to overlook these areas when addressing the mentioned issues. The common localization of these zones, well-connected and placed in the influence area of a city, gives them a high probability to be absorbed by the mixed-use urban tissue during the process of city growth. Planning urban logistic land considering its possible future conversion into mixed-use urban fabric becomes a pressing concern. The study analyses industrial areas that have been transformed into mixed-use urban tissue to, subsequently, stablishing a correlation between them and current logistic zones. In the case of logistic areas, special attention should be paid to transportation infrastructures, legislation and land-use organization, ecosystem preservation and mixed-use progressive introduction. The objective is to foster the planning of logistic land considering its potential future re-use and transformation into mixed-use urban tissue with low energy costs.
\end{abstract}

Keywords: Urban planning; adaptive re-use; logistic areas; urban transformation

\section{Citation \\ Alonso-Montolio, C. et al. (2021). Renewable Land: Planning the Evolution of Logistic Areas. ACE: Architecture, City and Environment, 16(47), 9042. DOH http://dx.doi.org/10.5821/ace.16.47.9042 \\ La Planificación de Áreas Logísticas como estrategia para una reutilización del territorio}

Resumen

\begin{abstract}
El territorio es un recurso finito, soporte de la vida y generador de los ciclos del agua y la energía en el planeta. La primera consecuencia del crecimiento de la población urbana y de la expansión del entorno construido es el consumo de suelo. En la actualidad, hay estrategias para reducir este gasto, por ejemplo, moderando el crecimiento disperso, favoreciendo los modelos de ciudad compacta y reutilizando el parque construido. Un porcentaje considerable del suelo urbano actual se destina a usos logísticos y esta proporción va en aumento como consecuencia de las economías deslocalizadas. Sin embargo, las estrategias de planificación urbana parecen pasar por alto estas áreas logísticas. La localización de estas zonas, bien conectadas y situadas en el área de influencia de una ciudad, les confiere una alta probabilidad de ser absorbidas por el tejido urbano de uso mixto durante el proceso de crecimiento de ésta. Por esa razón, la planificación del suelo logístico urbano, teniendo en cuenta su posible conversión futura en un tejido urbano de uso mixto, se convierte en un reto urgente. El estudio analiza algunas zonas industriales que se han transformado en tejido urbano de uso mixto para establecer una correlación entre ellas y las zonas logísticas actuales. En el caso de las áreas logísticas hay que prestar especial atención a las infraestructuras de transporte, la legislación, el uso del suelo, la preservación del ecosistema, así como la introducción progresiva de usos mixtos. El objetivo es concienciar a los profesionales de la planificación sobre la importancia de la planificación del suelo logístico teniendo en cuenta su posible reutilización futura en un tejido urbano de uso mixto y su transformación con bajos costes energéticos y medio ambientales.
\end{abstract}

Palabras clave: Planificación urbana; reutilización; áreas logísticas; transformación urbana

1 Ph.D. Architect, Architectural Technology Department, TA, Universitat Politècnica de Catalunya, UPC (ORCiD: 0000-0003-0877-7212; Scopus Author ID: 55537501600; WoS ResearcherID: K-5366-2017) ${ }^{2}$ M.Sc. Architect, Researcher, École Polytechnique Fédérale de Lausanne, EPFL (ORCiD: 0000-0003-2880-3115, Scopus Author ID: 57191873543; ResearcherID: J-8290-2017), ${ }^{3}$ Ph.D. in Physics, Professor, Department in Physics, Universitat Politècnica de Catalunya, UPC (ORCiD: 0000-0002-4354-5831, Scopus Author ID: 7004080030, WoS ResearcherID: M-2459-2014). Contact e-mail: carlos.alonso-montolio@upc.edu 


\section{Introduction. Planning for the future}

Cities are very complex systems in which many factors are concurrent. A large part of world population is currently living in urban centres, and this proportion is continuously increasing. While in 1960 the urban population was a 34\% of the total global population, in 2014 it accounted for a 54\% (World Health Organization). Consequently, resources, goods and energy needed in cities, transportation issues and the disposal of residues are becoming of great interest. The availability to most resources and energies is closely related to one item: the territory. Growth has no set limits in terms of population or resource use beyond which lies ecological disaster. Different limits hold for the use of energy, materials, water, and land (UN. Secretary-General, 1987). Land is the first resource consumed by cities expansion and the basis for others and, therefore, central in the present situation.

From the 1930's with the automobile democratization approach (Montgomery, 2013), cities expansion has often followed the urban sprawl paradigmatic (Montgomery, 2013, Ewing, 1994). In this model, low density extensions occupy a vast amount of territory with a lower population/land occupation ratio compared with the traditional compact city. This situation, connected with higher land consumption, produces significant increase on the cost per inhabitant of urban services - as water and electric power supply nets, sewage, roads/streets, transportation - due to the higher dispersion of people (US Government, 1974, Trubka et al., 2010, Burchell et al., 1998), among other negative consequences related with social isolation, segregation and environmental impacts (Montgomery, 2013, Jacobs, 1992). General research conclusions seem to indicate the advantages of compact cities (Montgomery, 2013, US Government, 1974, Trubka et al., 2010, Jacobs, 1992, Dantzing et al., 1973) and urban planning principles are currently favouring this type of growing and filling-up strategies.

Whereas the average life expectancy of buildings can be from 50 to 100 years, urban planning has a much longer time scale. For instance, in Europe, many old town centre cities remain very similar to the original tissue or are based on urban infrastructures, which can be far more than 1,000 years old (Rodrigue, 2006). In general, no significant areas of old cities parts have been dramatically rearranged, with the exception of the results of catastrophic events, such as war (Rotterdam after WWII bombing), earthquakes (Lisbon in 1755) or fires (Rome under Nero). Although it is possible to find examples of specific interventions that adapt old tissues to modern needs (Haussmann in Paris, 1852-1870), the general tendency is the preservation of the urban layout over time. A representative case of infrastructure longevity (Roman roads in the old Roman Empire (Rodrigue, 2006). From this perspective, it can be concluded that decisions in urbanism carry very powerful long-time consequences and might be difficult to modify subsequently. The tramline of a road can last thousands of years and social dynamics resulting from urban patterns can determine a neighbourhood's future. The responsibility of the urban planning discipline regarding future possibilities is imposing and its challenge increased by the uncertainty of prospective situations. Consequently, considering the transcendent character of city planning and its forthcoming consequences, urban strategies should be able to adapt to a future still unknown.

Logistics consider the wide set of activities dedicated to the transformation and circulation of goods, such as the material supply of production, the core distribution and transport function, wholesale and retail and also the provision of households with consumer goods as well as the related information flows (Handfield and Nichols, 1999).

The objective of this study is to discuss the importance of reusable/renewable planning in the case of logistic areas and, therefore, underline that planning these zones while considering their possible transformation into mixed-use urban tissue is crucial to ensure an appropriate conversion in terms of energy consumption and economic value. In order to stablish the main principles to consider in the planning process, a comparison with traditional industrial areas is carried out. The work is centred in Mediterranean areas. The case study used to draw references and establish comparisons is the Metropolitan Area of Barcelona AMB (Regió Metropolitana de Barcelona, 2009). Situated in the North 
East Mediterranean Coast of Spain, this area is significant for the discussion because it is where the first industrial revolution of the country took place, encouraged by social factors, such as the presence of an investment bourgeois class, and by some favourable geographic reasons, like the strategic location of its harbour (Figure 1).

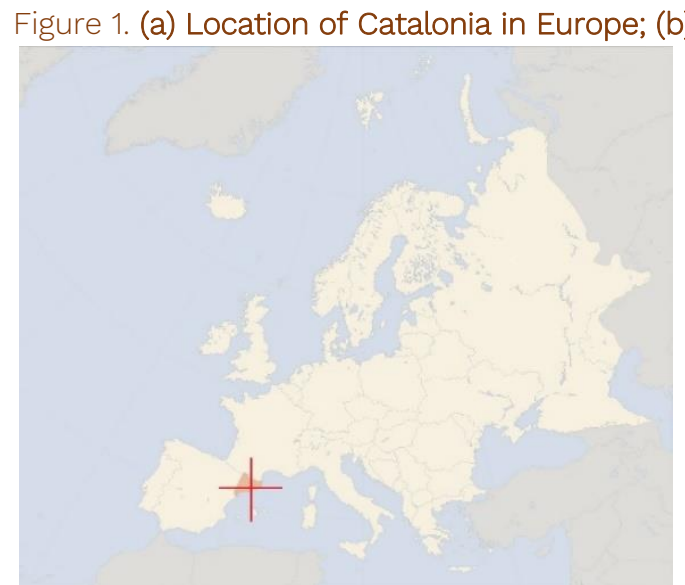

Source: (a) Prepared by the authors; (b) Google maps (b) Aerial image of Metropolitan Area of Barcelona

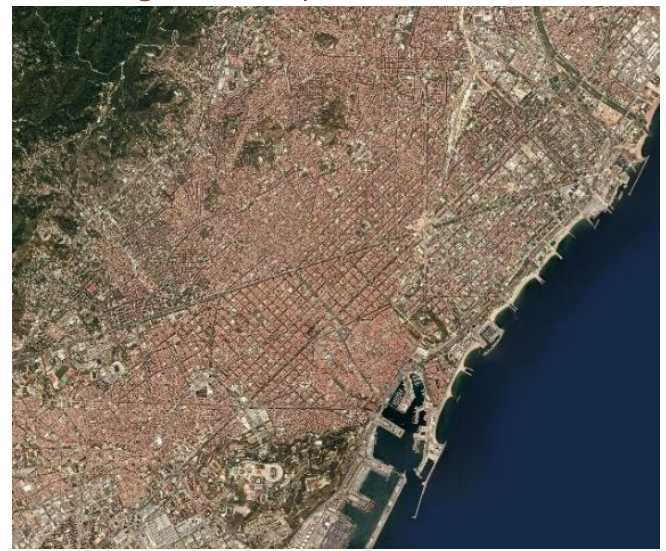

\section{Land use and cities. The importance of logistical areas}

Urban land distribution in sectors comprises several uses, such as residential areas, public and private services, infrastructures and productive centres that range from manufacturing and logistics to offices and entrepreneurs' sites (urban land in Spain is near 4\%, Table 1). Although the quantity of space assigned for each use can vary greatly, industrial and logistic areas take a noteworthy amount of land in modern cities.

Table 1. The land use distribution in Spain for a total of $506.041 \mathrm{~km}^{2}$

\begin{tabular}{|l|l|}
\hline Type of Land & Percentage of total \\
\hline \hline Urban, including driveways & $3.7 \%$ \\
\hline Agriculture & $37.7 \%$ \\
\hline Forest and others & $58.6 \%$ \\
\hline
\end{tabular}

Source: Goerlich-Gisbert, 2013.

Table 2. Catalonia's main division of land: urban, agriculture and forest, in 1993, 2005 and 2018

\begin{tabular}{|l|c|c|c|}
\hline Type of Land & 1993 & 2005 & 2018 \\
\hline \hline Urban & $134,000 \mathrm{Ha} .(4.2 \%)$ & $165,794 \mathrm{Ha} .(5.2 \%)$ & $21,8370 \mathrm{Ha} .(6.8 \%)$ \\
\hline Agriculture & $1,107,000 \mathrm{Ha} .(34.6 \%)$ & $972,346 \mathrm{Ha}$. (30.5\%) & $941,792 \mathrm{Ha.}(29.3 \%)$ \\
\hline Forest and others & $1,954,000 \mathrm{Ha}$. (61.2\%) & $2,054,917 \mathrm{Ha}$. (64.4\%) & $2,050,628 \mathrm{Ha}$. (63.9\%) \\
\hline
\end{tabular}

Source: Generalitat de Catalunya. Note: For the medium industrialized Catalonia (Northeast of Spain), table 2 shows the main division of land, as urban, agriculture and forest, in 1993, in 2005 and in 2018. Urban soil increased around 25\% in 12 years, while the population increased around 1 million people (in 2005) over the near 6.1 million in 1993, so only a 16\% (Ibáñez, Burriel, 2010). From data in table 2, it can be seen that, in Catalonia, more than 5\% of land was urban in 2005 and that this percentage increased in 2018.

For instance, in 2005, around 38.000 Ha were industrial, logistics or commercial areas in Catalonia, accounting for nearly one quarter of total urban land (Table 2). Industrial, commercial and logistic zones tend to be located close to urban centers to reduce costs of goods and workforce 
transportation and to benefit from agglomeration economies (Rodrigue, 2006). Consequently, these areas can be found contiguous or very close to consolidated central urban land, increasing its possibilities of being absorbed by it (Font et al., 2008).

Figure 2. Percentage of industrial land on urban land in the AMB.

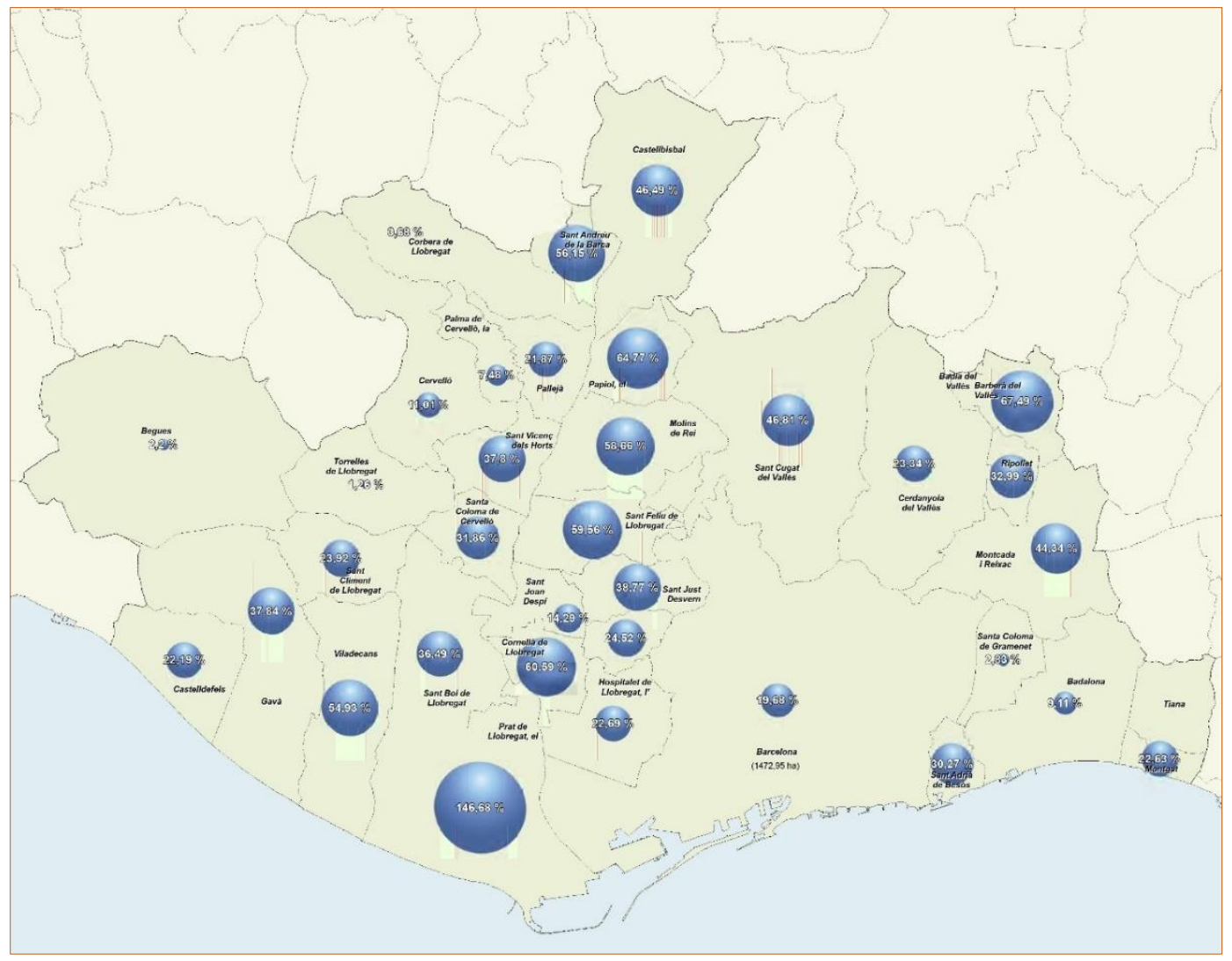

Sòl industrial sobre sòl urbà (\%)
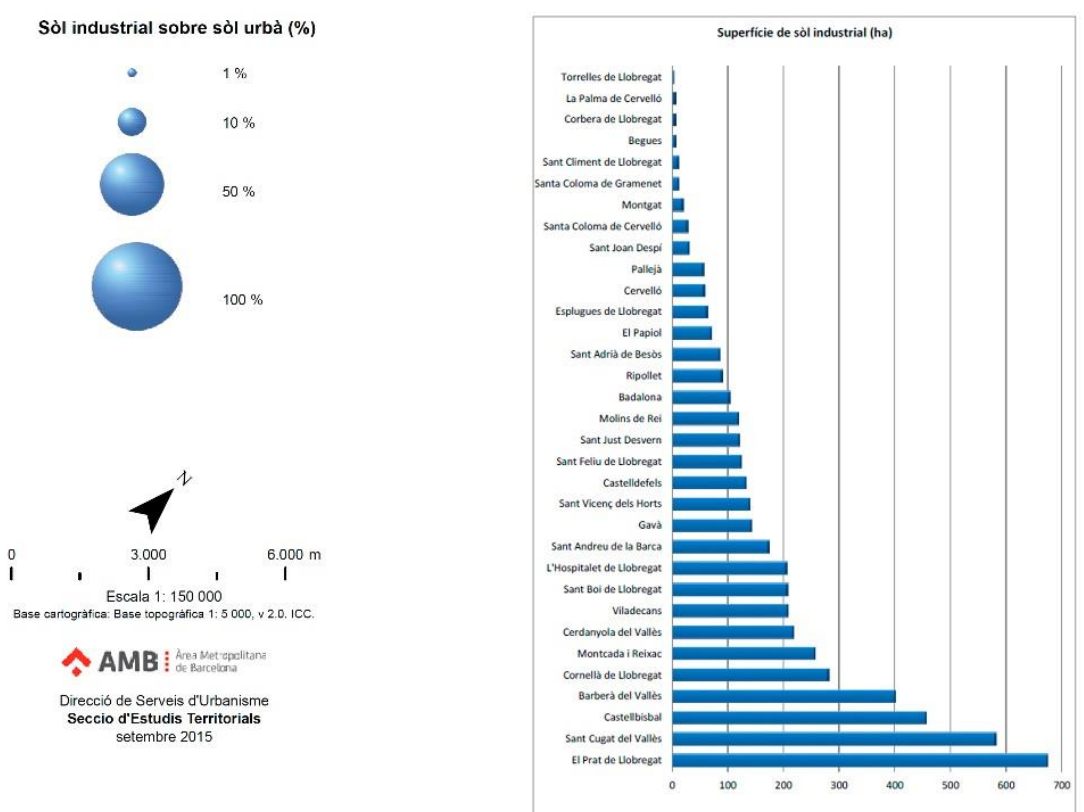

Source: AMB, 2015 (www3.amb.cat/repositori/Estudis\%20territorials/PAEP_informe_2015r.pdf).

ACE, 16 (47) CC BY-ND 3.0 ES | UPC Barcelona, España | Renewable Land: Planning the Evolution of Logistic Areas. 
Generally, the territorial relevance of these zones has failed to be acknowledged and supported by appropriate urban planning strategies, especially considering their forthcoming possibilities. As these uses benefit from being adjacent and well connected to urban centers and given the tendency to increase the number of people in urban context, their future as areas spatially absorbed by city tissues seems predictable. Nonetheless, in the present situation, the transformation potential of logistics and industrial zones, when accounting its cost, is being restrained by their original planned use.

The new information era brings a clear consequence: the delocalization of production and services and, therefore, industry. On the one hand, this situation allows a freeing of city spaces from productive sectors. On the other hand, the logistic infrastructure to back-up this delocalized system increases. As goods need to reach their final destination with less mobile participation from consumers, freight transport absorbs this mobility sector and more logistic areas are needed to support the system (Verhetsel et al., 2015, Tatjer, 2006, Crainic et al., 2004, Muñuzuri et al., 2005). Consequently, to be able to achieve an industry based in renewable premises, as the EC Communication demands (European parliament, 2013), management and logistic areas should be seriously addressed.

\section{Current logistic zones}

A logistic zone can be defined as a "Grouping of activities dealing with freight distribution such as distribution centres (warehousing, storage and light industry), transportation (freight forwarders, shippers, transport operators, customs brokers) and supporting services (human resources, maintenance and repair) within a defined and often planned area". In Europe, logistic zones were defined as such in the late 1960's and 1970's in France, Italy and Germany, being multiplied and extended in the 1980's and 1990's. Nowadays, it is a well-advanced concept that is growing proportionally with the globalized economies (Rodrigue, 2006). Dr Jean-Paul Rodrigue stablishes four main types of logistic areas based on a modal taxonomy. Firstly, a port-centric logistic zone (a), planned in proximity to a port terminal. Its activity is centered on freight distribution activities in relation with marine shipping with a special international focus, such as the case of Barcelona's Containers Terminal (BEST). Secondly, an inland port or dry port (b), is an intermodal terminal is an area often serviced by rail or trucks related to adjacent logistical and service activities. A logistics park (c) is an area that gathers distribution centers and light manufacturing activities, offering advantages of favorable regulations and agglomeration economies. Finally, a freight village (d) is a cluster centered on service that integrates support activities of freight distribution as hotels, restaurants, fueling stations or office space. The main requirements for site selection of logistic land can be divided in five main groups. Firstly, labor costs and easy access to diversified skilled workforce. Secondly, accessibility, as transportation costs are crucial in freight distribution (Verhetsel et al., 2015). Another important aspect is the availability and cost of land, as this kind of activities consume a large amount of space (Rodrigue, 2006, Verhetsel et al., 2015). However, the possibilities of densification are highly correlated with technological investment (Isalgue et al., 2014). Connected with this point, the access to the necessary infrastructures that support the activities needs to be concomitant to the acquired land and support the main needs of the activity performed. Finally, the presence of anchor tenants, or large logistic firms bringing capital investment, expertise and cargo volume.

\section{Industrial areas as an entry point to evaluate future transformation of logistic land}

Logistic zones, as we currently know them, have a short history as a stand-alone system due to the fact that, previously, they were strongly intertwined with industrial zones. Therefore, in this study, we are using industrial areas as a precedent that might be useful to detect possible patterns in the future development of logistic land.

ACE, 16 (4.7) CC BY-ND 3.0 ES | UPC Barcelona, España | Renewable Land: Planning the Evolution of Logistic Areas. 
Industrial areas have been colonizing the territory since the 19th Century. In Spain, the first industrial revolution flourishes in two specific Northern areas: Catalonia, closely related to the textile sector, and the Basque Country, specialized in the metallurgical. Our analysis will be focused in the Barcelona Metropolitan Area (AMB), although it could be applied to other cases (Figure 2). Therefore, this section will develop the transformation of industrial land into mixed-use urban tissue in the AMB with the aim of being able to draw a parallelism with current logistic areas.

Industrial areas are generally located either close to raw materials or energy sources of the first Industrial Era or locations with specific potentials related with social, geographic and historical factors. In the case of Barcelona, their location is more related with the historical factors such as a previous strong pre-industrial productive tissue in the city, geographical reasons, as the strategical importance of the Barcelona port, and social factors, as the presence of a rising bourgeois class eager to invest in the industrial sector. The industrial process can be classified in three main periods, the first being linked to the steam engine, the second to the electricity and, finally, the last one connected with the use of oil and the rise of the car and electronic industry (Lo Cigno, 2011). Regarding their potential of transformation usually related with their typology, industries can also be divided in three types:

\subsection{Industry built inside existing tissue}

This type generally follows the model of house-industry (Capel, 1996), usually adjacent parcels sharing party walls with different uses in several stores that comprises the owners dwelling (Tatjer, 2006) (Figures 3, 4 and 5). An example of this model is one of the early factories implemented in Barcelona with steam machine, the "Fabrica Bonaplata". Some other cases of this type exploited terrain with a previous use (monasteries, storage, harbors...) that allowed the implantation of a large construction. This type of industry usually follows a recessive transformation process, being easily engulfed by the surrounding tissue when its industrial use is no longer valid. Their small scale facilitates their transformation in regular residential or offices tissue (Artigues et al., 2013).

Figure 3. Census of industries in the neighborhood of Raval, center of Barcelona

Source: MUHBA Documents. núm. 6

ACE, 16 (47) CC BY-ND 3.0 ES | UPC Barcelona, España | Renewable Land: Planning the Evolution of Logistic Areas. 
Figure 4. Casa Fàbrica Domènec. Typical house-industry model at Aurora Street

\section{C. de l'Aurora, 12}
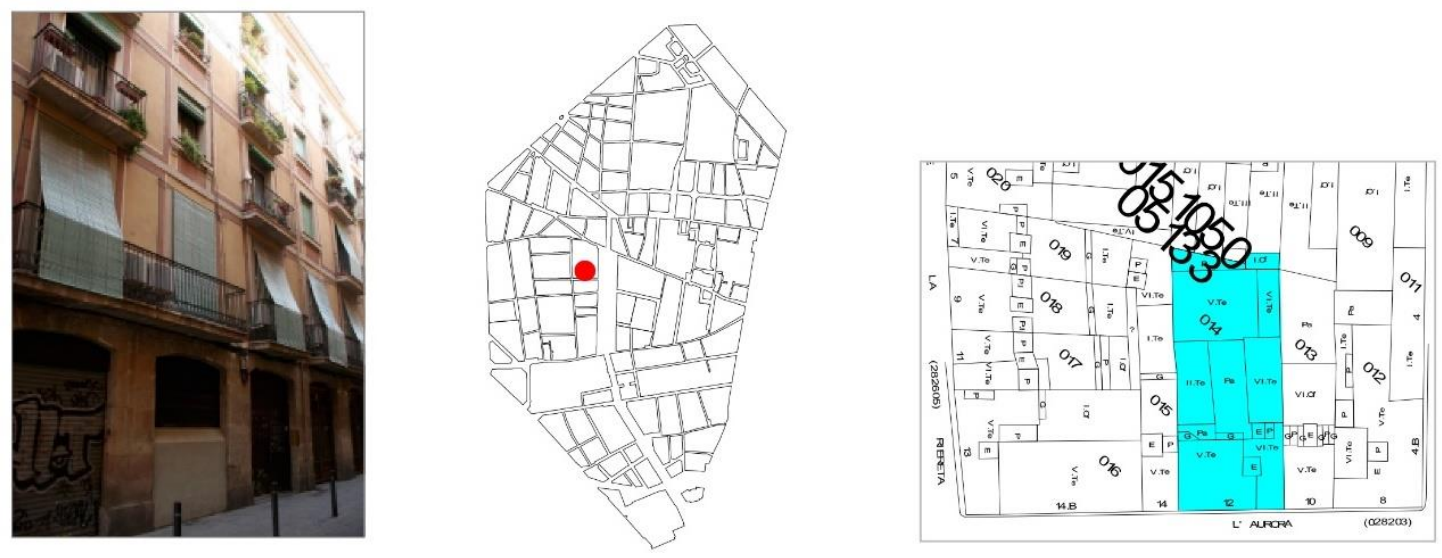

Source: MUHBA Documents. núm. 6

Figure 5. Typical house-industry model at Reina Amàlia Street

\section{C. de la Reina Amàlia, 6}
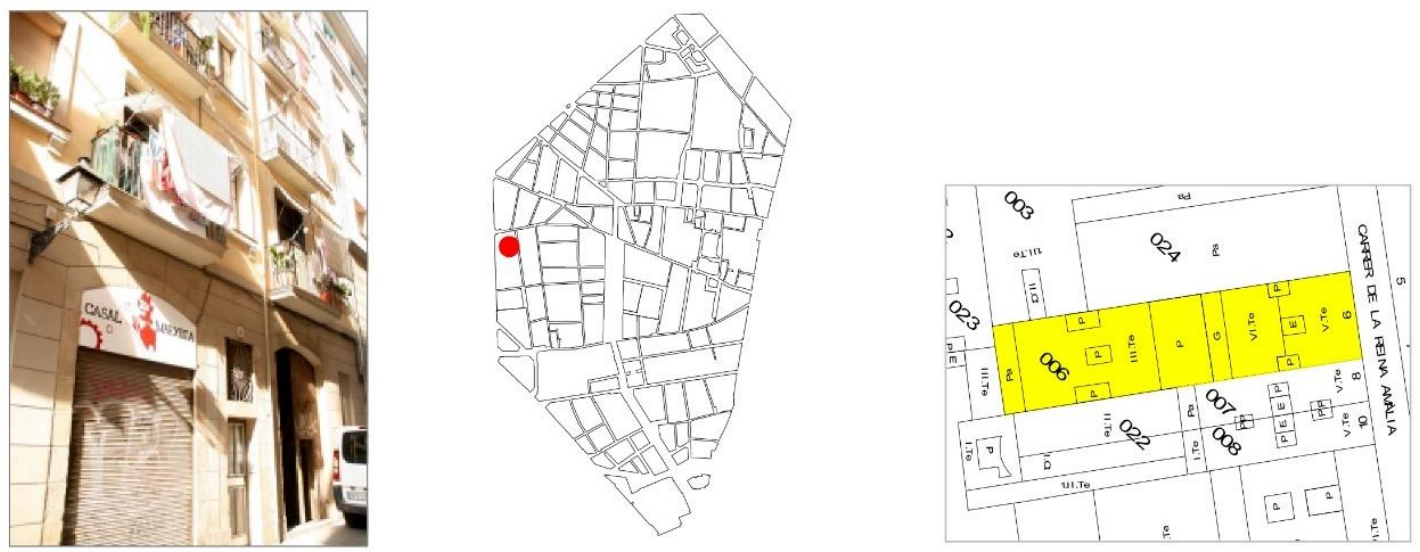

Source: MUHBA Documents. núm. 6

\subsection{Industry absorbed inside the growing tissue}

This type generally Factories placed next to the existing urban central tissue but not physically connected. Usually their disconnection is a result of the type of activity developed in the industry at the beginning, source of disturbing factors such as smell, noise, smog and so on. With the growth of the city, the industry is to be absorbed inside the urban tissue (Lo Cigno, 2011) (Figure 6). Their location is often related with the presence of transports and communication infrastructures. An example of this type of industry in Barcelona could be "la Escocesa" (Figure 7).

Industries that, as a result of urban growth, end up becoming a piece with a larger scale in comparison with the surrounding tissues usually undergo one of the following types of transformation. The first strategy implemented, generally related with property speculation, is the demolition of the existing industry and the exploitation of the land obtained through the building of a residential area. In 
occasions, this procedure is connected with a legal reclassifying of land. In this case, the emptied space obtained, with larger dimensions than the surrounding tissue, is fragmented again (Tatjer, 2006). The second implemented approach recognizes the value of a large portion of empty terrain inside a consolidated urban tissue and demolishes the existing industries constructions to build public buildings or other uses in need of great extensions (see, for example, Figure 8) (Tatjer, 2006). Finally, the last approach is the transformation of the use of the existing building, preserving the main architectonic features, but implementing a new use, usually a service. Re-using the building offers the possibility of preserving its historical memory and, in this way, transforming it into a new neighbourhood centre with social meaning (Lo Cigno, 2011). This type of transformation usually is associated with an increase of the value of the surrounding area (Tatjer, 2006). This value not only depends on the geographical distance to the city centre, but it also depends on the social aspects. The social adequacy of the intervention is significant (Marmolejo Duarte et al., 2016). It is necessary to carefully analyze how to improve degraded peripheries, often occupied by housing settlements in former logistic or industrial areas (Cerasoli, 2010). It should also be mentioned that large transformations developed too quickly tend to a social substitution in urban spaces (Brites, 2016). Therefore, large transformations should be carefully developed.

Figure 6. With city growth, industries originally located at the periphery are
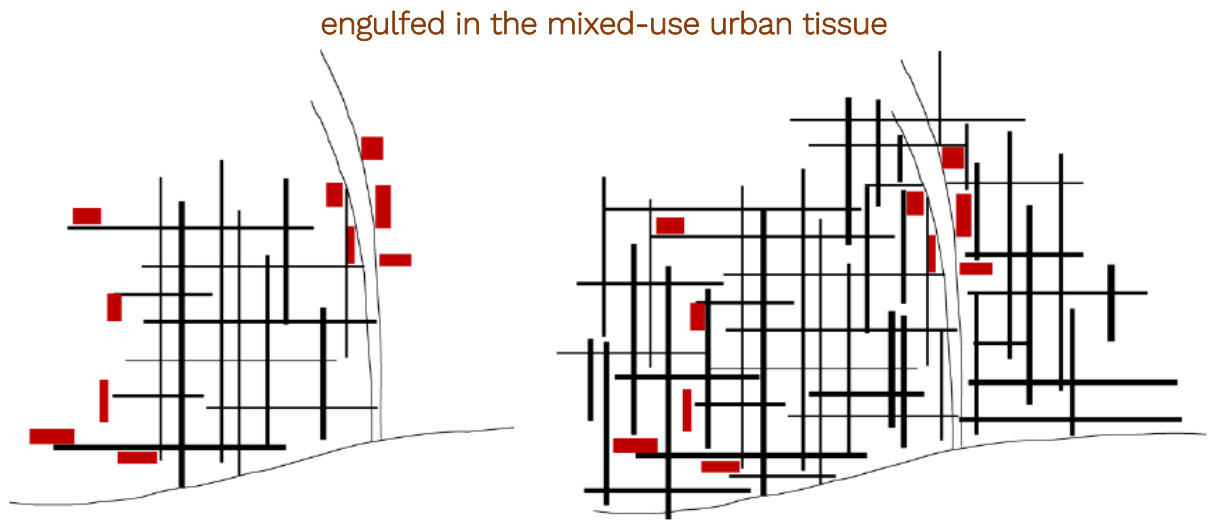

Source: Lo Cigno, 2011

On the other hand, this strategy can also be focused on the objective of improving the city's image through tourism by attracting visitors to secondary areas through the introduction of a cultural use in a recovered historical building (Capel, 1996, Navratil et al., 2018). However, the recovery of industrial buildings is still a new tendency and often the value of the historical heritage of this sector is not appreciated (Font et al., 2008, Tatjer, 2006).

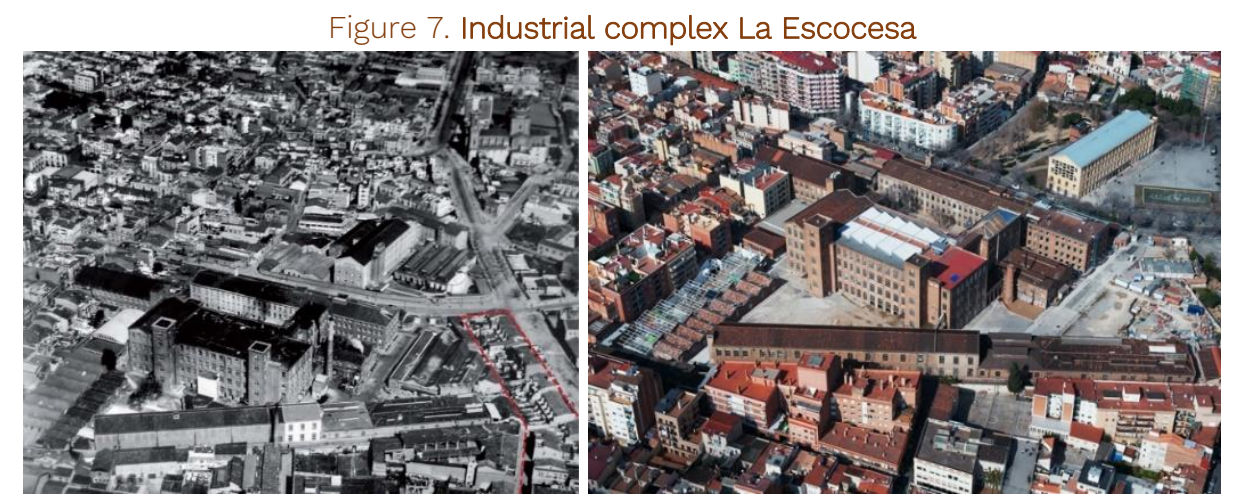

Source: (a) http://ernestgarriga-arq.blogspot.com.es/; (b) http://ajuntament.barcelona.cat/fabraicoatsespais/es/ detall/institut-marti-pous_99400380477.html Note: (a) Industrial complex 1852.; (b) Current transformation into a Creation Centre for the neighbourhood 


\section{ACE Architecture, City and Environment}

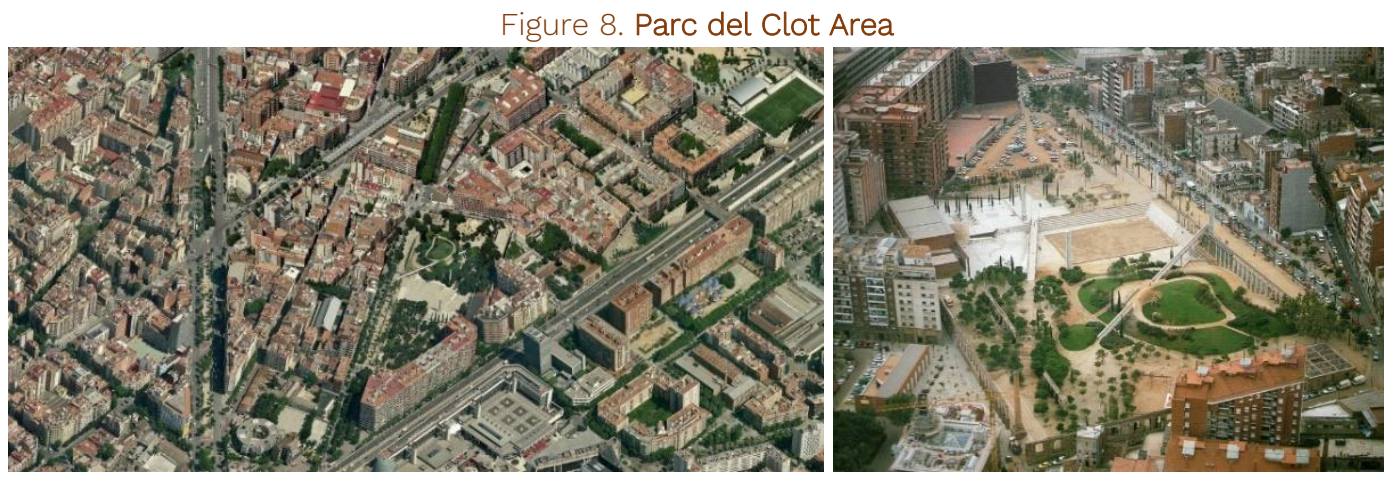

Source: bing maps. 2011. Note: (a) The former Industrial building is a larger piece compared with the surrounding urban tissue; (b) The large empty space is used to build a park inside a dense residential urban tissue

\subsection{Industry built as part of an industrial tissue}

This type is composed by several factories and industries grouped in industrial tissue. It is generally connected with the second industrial era and the introduction of new energy sources (Lo Cigno, 2011) and the urban principles of the 20th century that implemented the zoning strategies (Tatjer, 2006). During the 20th Century, the average of size of industries increases and clusters of emergent sectors start to give shape to the new industrial areas. This situation brings as a result a change of scale and content in the industrial landscape, favouring the organization in great surfaces and complexes. Examples of these types of industrial tissue in Barcelona are Poblenou and La Zona Franca, this second one being one important industrial polygon in Europe (600 Ha, 250 companies, 43.000 workers) (Figure 9a) (Tatjer, 2006).

Figure 9. Industrial areas of Barcelona: (a) Zona Franca and (b) 22@ district
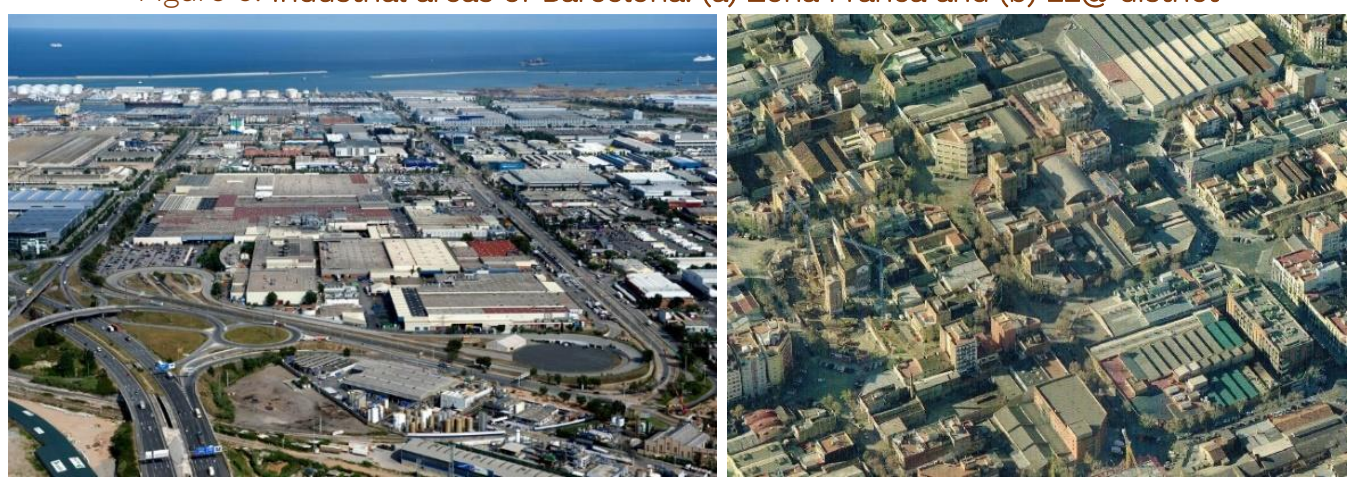

Source: (a) http://www.economiadigital.es; (b) Busquets et al., 2009. Note: (a) Partial view of Zona Franca, Industrial area of Barcelona; (b) 22@ district in the Poblenou, a former industrial area of Barcelona and now being transformed into an innovation center

The transformation of these areas into mixed use urban tissue is, generally, a process still under construction or even just a future project and, therefore, it is difficult to analyse the results (Tatjer, 2006). However, there are some factors that seem to act as a common denominator of these cases. Firstly, the low quality of industrial buildings architecture and construction and, therefore, their fast degradation complicating their re-use possibilities. In relation with this factor, observations show that older industrial buildings (19th Century) are more often preserved and re-used in these clusters, while more modern constructions are demolished and replaced by new architecture. The new uses implemented in these zones are generally of two different types, which sometimes can be found as a mixed tissue. When the area is not placed on a significant spot of the city or does not have an iconic

ACE, 16 (47) CC BY-ND 3.0 ES | UPC Barcelona, España | Renewable Land: Planning the Evolution of Logistic Areas. 
industrial building, its fate tends to be a housing extension. On the other side, when the location or architecture items present in the area have a special interest, a new model is implemented which affirms its productive scope updating the product to the current times: information technologies. In this way, these areas are transformed into campus of knowledge transfer, innovation and research; centres of information production. An example of this phenomenon in Barcelona is the 22@ district (Ajuntament de Barcelona, 2012) (Figure 9b). There is a third type of transformation with different initial premises that should also be mentioned. In the cases of large extensions of land that used to be heavy or contaminating industry or infrastructure, its transformation into urban tissue might be complicated. There are examples of re-use that transform these areas into parks or vegetal extensions, which can also include depurating natural processes. It is representative the well-known example of the High line in New York or the Duisburg Nord Park in Germany.

The usual process of transformation of logistic areas tends to follow the subsequent change chain: Industrial area, clean industrial area, warehouses (logistics), commercial and, finally, residential. (Qiu et al. 2015; Aljohani, 2016; Guerlain et al. 2019; Russo et al. 2020). Consequently, logistic areas tend to have a similar structure to previous industrial areas and current industrial and commercial zones, usually following the organization of the third analysed type. Firstly, the access to the whole zone tends to be limited to few routes in order to enable an easier control. The opposite strategy is usually applied to classical successful urban zones (residential and services), which can be accessed via a relatively high number of streets or roads. Secondly, the size of the used blocks is generally larger than those used in classical urban spaces. The streets of industrial zones are also in average generally wider than the ones in residential areas. Finally, transportation in industrial and commercial zones is designed for goods as a priority (truck transport easy), while transport in residential zones is generally intended for people, with related needed services as subway, tramway, bicycle lanes.

\section{Adaptive reuse and cost of land reconversion (Future of areas)}

An increasing interest in reducing the impact of urban development is perceived (Campos-Sánchez et al., 2018 and references therein). One of the ways to minimize the impact would be allowing the land devoted to one type of use to be adapted to other uses. Adaptive reuse has been defined as "a process that changes a disused or ineffective item into a new item that can be used for a different purpose" (Royal Australian Institute of Architects, 2004) and it is acknowledged as a strategy "to ameliorate financial, environmental and social performance of buildings" (Langston et al., 2007, Bullen, 2007). Consequently, by reducing the quantity of embodied energy needed to supply a built infrastructure suited for the new purpose, this process can contribute to a more environmental caring and energy consumption reduction path (Bullen, 2007).

The importance of this strategy is strengthened at an urban scale, where to the whole-life energy costs of transformation do not only involve the building scale but also the main urban infrastructures, generally with a longer time-span. Costs of land reconversion - sewage, water supply, electrical power lines, water collection, streets, vegetation and so on - can be very significant in the overall of an urban project and have always been a great concern when dealing with urban expansion (Herce, Miro, 2012). Furthermore, the economic efficiency of urban adaptive reuse can be considered as accomplished when benefits of the project, such as job creation, areas revitalisation or tourism as an economic success, outweigh its costs (Yung, Chan, 2012). Consequently, to be able to achieve a positive balance, the objective is to lower urban transformation costs and increase final benefits. On the other hand, it has to be considered that building regulations, availability of services and transportation, means of access and scape and planning or environmental regulations can highly affect the feasibility and cost involved in the transformation (Langston et al., 2007, Yung, Chan, 2012, Li et al., 2018). 
The transformation of industrial land that has been analysed shows how, generally, the process is not a one-time operation but a series of successive rezoning carried out in different phases (Font et al., 2008). When the transformation leads to public buildings or facilities, a larger fraction of public space is obtained (Figure 10), while when the transformation leads to residential uses there is higher fragmentation (Valderrama et. al., 2021). The processes followed by industrial land that has been assimilated by the city and transformed into mixed-use urban areas can give us guidelines to predict the possible directions of logistic areas.

Figure 10. Transformation of industrial areas in the district Les Corts (Barcelona)

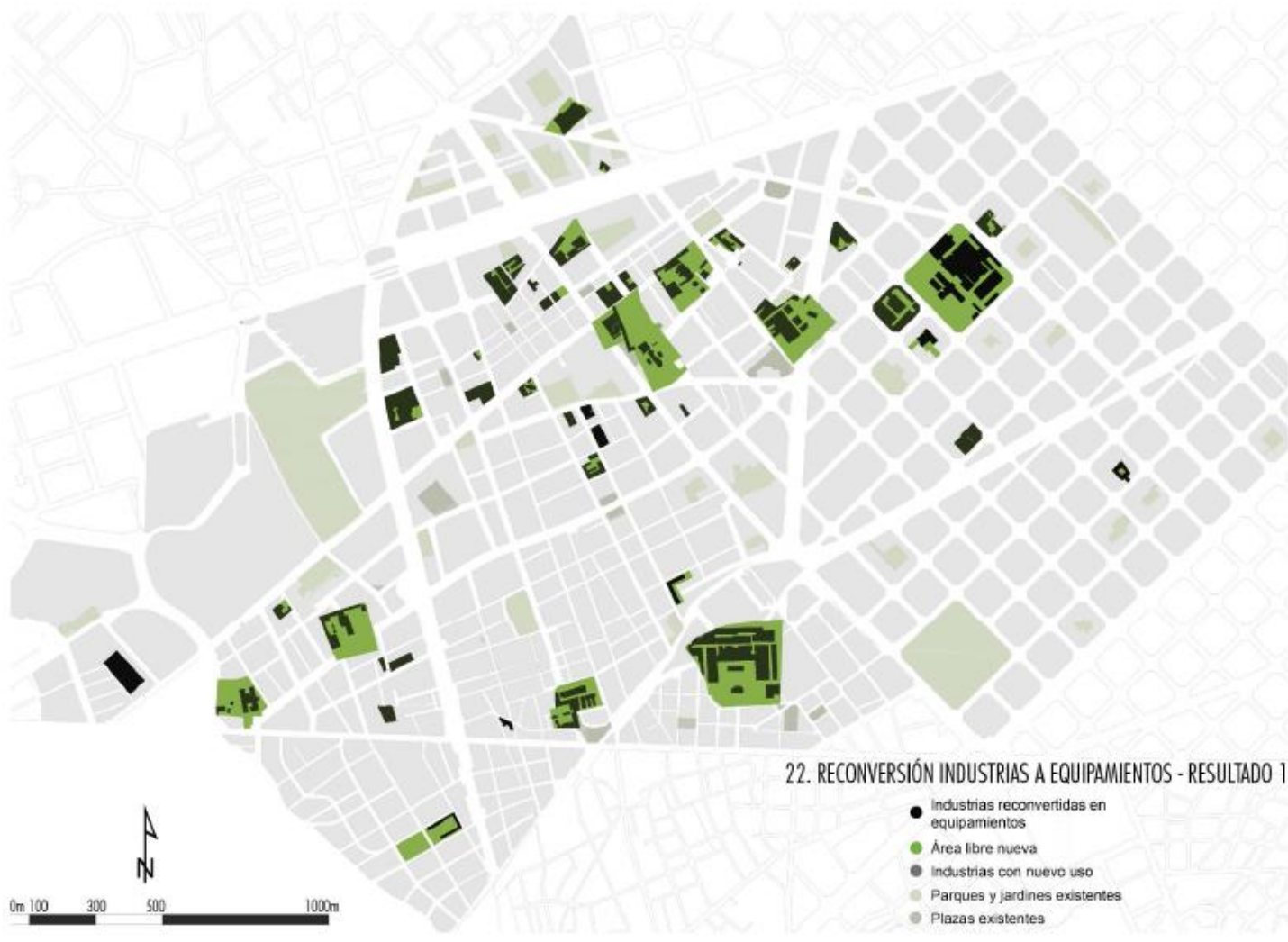

Source: Valderrama et. al. (2021).

To be able to achieve a feasible urban transformation from logistic areas to mixed-use urban areas, urbanisation costs, from an energetic and economic point of view, should be considered. The initial planning of these infrastructures and urban regulations of the area, when carried out considering their future possible reuse, can lower substantially their future transformation costs. Moreover, erroneous or inconvenient services may cause higher energy consumption not only during the period of transformation but also when the new use is implemented as, for instance, a lack of proper accesses to the area, larger distances for cars movement, difficulties for public transport meaning more car use and so on. From an economical point of view, if lower standing is achieved for the new transformed area, lower gains can be obtained from the land investment. In this way, the adaptive reuse of existent industrial areas into residence, services and commerce can foster a multiple use and functional mix together with avoiding a further expansion of building land (Sassi et al., 2009). "This strategy offers an effective response to the need to consolidate the inward development of towns and cities and, at the same time, it contributes to restricting urban sprawl." (Sassi et al., 2009). 


\section{Discussion}

The analysis of the logistic areas displays several aspects interesting to discuss, as we can see many common points with industrial areas. The current classification of planning distinguishes logistic and industrial areas, even if the industrial land has certain areas dedicated to logistics' activities internal to that industry. Currently, the tendency is to increase those logistic areas at the expense of the production area. Therefore, many lots nowadays classified as industrial could actually be completely logistics' focused. While this situation makes a detailed analysis complicated, the similarities mentioned make many cases fairly equivalent.

The accessibility to labour force has been labelled as a main driver for logistic areas location. Consequently, guaranteeing a proper connection with urban residential areas would involve an easier access to workforce during the logistics use period and a smoother transformation to posterior mixed urban tissue. Related with this issue, accessibility and transportation is crucial for the well-functioning of logistic areas and the logistic area fragmentation tactic depends on the available transport. Accordingly, providing good connections with the city and other logistic centres is beneficial when the area is a freight distribution pole but also this would be favourable for its future transformation (Polígons d'activitat econòmica i productiva a l'AMB, 2015).

Furthermore, it can be stated that the land value has the highest rising in time, compared with the other values affecting the logistic performance of the area, such as workforce or technology investment (Isalgue et al., 2014). Its original cost also bears a great importance on the location selection (Rodrigue, 2006). The filling-in strategies in these areas are directly related with technological investment and transport possibilities.

Finally, the attraction of anchor tenants can be driven by the long-term possibilities of the area and, therefore, its possible re-urbanization and its costs can affect firms' capital strategies. Introducing mixed-use in logistic areas in the verge of transformation has been shown as a positive investment for the land owners. However, if the change from industrial to mixed-use were less costly, in terms of infrastructure investment and time of transformation, the margin of profit would increase.

The analysis of the industry evolution as a parallelism with logistic areas brought other observations. Firstly, the affinities between industrial and logistic areas in relation with their possible transformation and re-use are more generally based on the transport infrastructures and land organization than in buildings. Secondly, the information-based society and delocalization phenomenon brings as a consequence an increase of logistics. Finally, logistic areas are based on the same premises that 20th Century industry, with separated zones that are connected with the cities through transport infrastructures.

In most western societies, the industrial revolution brought densification of cities and increased hygienic and health problems in urban areas. Rational urban planning was the tool implemented to address those issues, developing the concept of zoning regulations, which prioritized the separations of uses to avoid problematic nuisances. In this way, smoke and contamination from industries were separated from areas zoned as residential.

However, recently, urban planning theory has challenged this approach, developing an inclination for mixed use and breaking the traditional zoning regulations based on segregation of uses. While other uses, such as office, residential, entertainment and retail have been successfully integrated in many urban areas, industrial and logistical areas are still planned as separate structures outside of the urban tissue (Tatjer, 2006). 


\section{Conclusions}

The idea of planning land use for it to be reusable/renewable responds to the need to avoid the increase of goods and energy used in the transformation process and achieve a higher standard end solution.

Considering the weight of transportation in the location and performance of logistic areas together with the temporal permanence of transport infrastructures, one of the main areas to focus when planning renewable land strategies is mobility. This subject can be addressed from three main points of view. Firstly, when organizing transportation inside the area, infrastructures such as roads or streets - and other urban infrastructures connected with - should have an organization and scale closer to well-functioning residential and mixed-use. Consequently, on one side, herringbone systems should be avoided, guaranteeing the presence of interconnected places and central spaces and, on the other side, blocks should be adapted to reduce their scale in order to adjust to residential uses - for instance, organizing the internal distribution infrastructures of logistic companies to be adapted in the future into urban streets. Secondly, when planning the relation of the logistic area with its surroundings, the possibility to increase its permeability in the future should be considered.

Therefore, although accesses would need to be restricted during the logistical use due to security reasons, possible new openings should be planned in concordance to the internal and external structure. Finally, the connection with other logistic areas and the city should not only focus on freight transport but also on people's circulation. In this way, logistic areas should be connected with transportation urban hubs in order to facilitate its access for workers and use these hubs as transportation urban centres (Crainic et al., 2004, Muñuzuri et al., 2005, Taniguchi et al, 1999). Nevertheless, transportation is not the only factor to bear in mind when addressing logistic areas planning with a renewable strategy in mind. Other important aspects must be considered.

The implementation, by government institutions, of legislation and property systems that fosters mixed use is decisive. In this way, there is a need to promote the implication of public institutions through a proper legislation and private sectors through investments that will produce future revenues. Although initial zoning regulations have been tied to separation of uses, current urban challenges demand a more flexible understanding of land use and zoning principles. Some of the directions that this change could take are the following: Firstly, a reconsideration of land use categories that may not align anymore with the types of uses of the city and their effects among each other. Secondly, the creation of a more flexible regulatory structure that allows for progressive transformation. Finally, a more in depth understanding of the workspace, industry and logistics that fosters an easier combination of different uses that might be compatible but are now disregarded because they fall in larger exclusive categories.

The study of industrial areas' evolution has allowed us to detect the different activities carried out within lots characterized as industrial. These parcels hosted from productive functions to storage of raw materials, manufactured product, vehicles, machinery, as well as office buildings, sales areas and, in some cases, even exhibition spaces. This mixture led to a subsequent not planned segregation of parcels, generally motivated by the increase of the land-value. These big parcels were originally located in low-value areas and, through the price raise, progressively disintegrated in smaller parcels without following any planning directions. Their common characteristics with logistic areas, great surface, low original land value and vagueness of the activities carried out, point out at the proclivity of the latter to follow the same path as their industrial precedents, and fall prey of purely speculative growth. 
These zones could foster the future transformation of the area, even being preserved after the consolidation of the urban tissue and having the possibility of acting as a tool to ensure the presence of public space and services when the residential expansion starts. Furthermore, in order to promote this planning strategy, benefits for investing in renewable urban infrastructures should be provided for the main stakeholders. Consequently, the possibility to make use of the profits of the urban transformation of logistical areas into mixed-use urban tissue, should be ensured for main original investors.

In conclusion, it is relevant to acknowledge land as a finite (and expensive) resource on Earth and, therefore, consider its reusable/renewable potential accordingly. Urbanistic decisions have consequences on a very large time scale, as the history of European cities shows, the urban tissue and street arrangements last much more than the average buildings do. Several current trends point out a growing importance of focusing on the management of urban land in general and logistical areas in particular. Firstly, urban areas are increasing its share of available land on the territory. Secondly, considering nowadays tendency of delocalizing industry and the logistics infrastructure needed to backup this trend, these areas and their management are becoming central for territory and urban planning. Finally, there has been a considerable growth of transport demand in terms of passengers and freight mobility. Consequently, the expansion of transhipping infrastructures and their need of improvement are crucial to ensure the well-being of the system (Figure 11).

Figure 11. Public railway-based transport in the Industrial areas of AMB

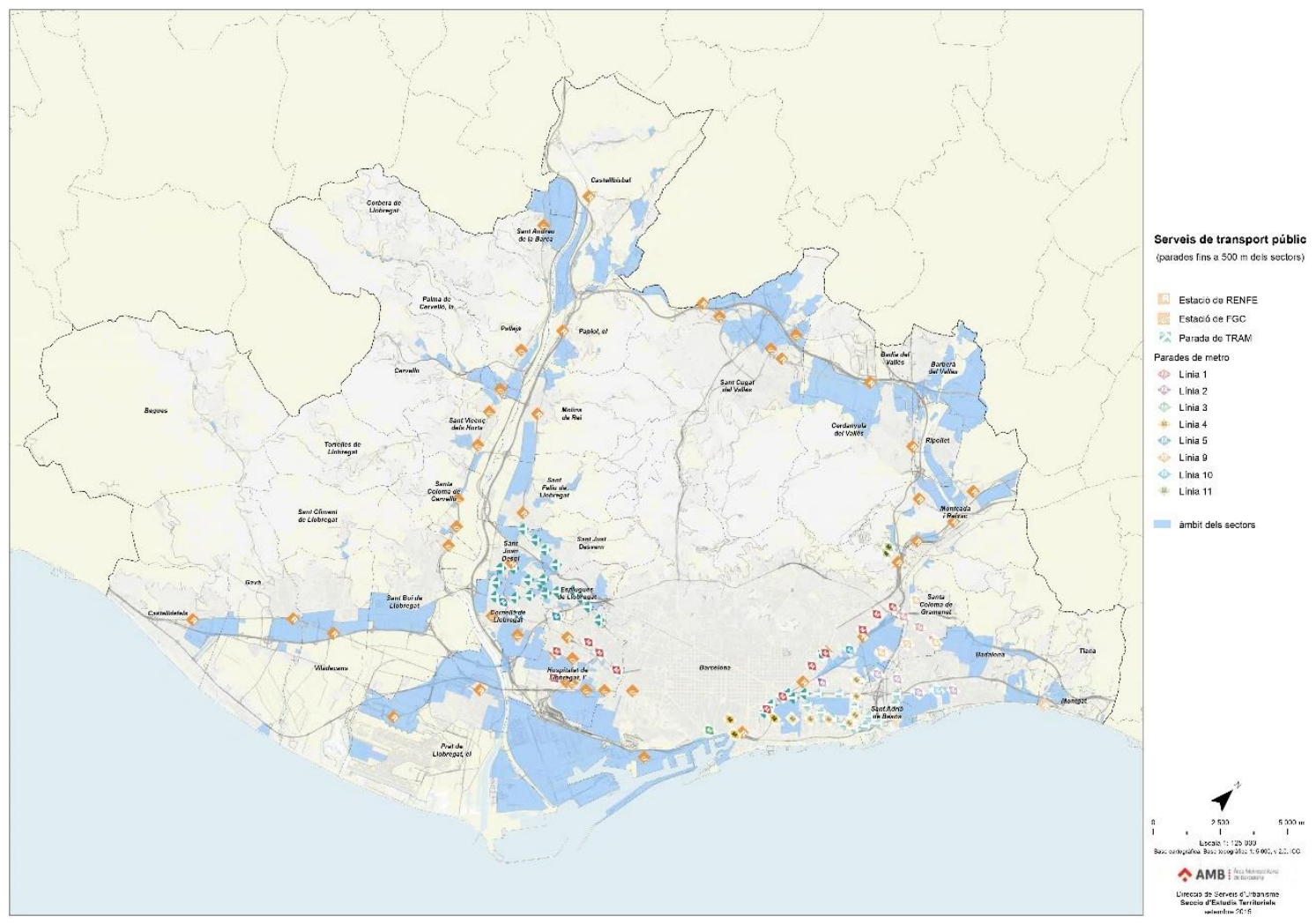

Source: AMB, 2015. www3.amb.cat/repositori/Estudis\%20territorials/PAEP_informe_2015r.pdf

In order to guarantee the possibility of expanding the life-service of a share of land avoiding major transformations that would carry great economic, energetic, environmental and social costs, the initial planning should consider flexibility and adaptability as central requirements. To translate this idea

ACE, 16 (47) CC BY-ND 3.0 ES | UPC Barcelona, España | Renewable Land: Planning the Evolution of Logistic Areas. 
into practice in the case of logistic areas, special attention should be paid to transportation infrastructures, legislation and land-use organization, ecosystem preservation and mixed-use progressive introduction. The objective is to foster the planning of logistic land considering its future transformation into mixed-use urban tissue. Nevertheless, further investigations should be carried out in order to determine the exact influence of these aspects in the energetic and environmental costs of adaptive reuse and the benefits drawn from its improvement.

\section{Acknowledgements}

This article is supported by the Spanish Government under the Project BIA2016-77675-R.

\section{Author Contributions}

The different knowledge and experience of each author have equally contributed to the development and final version of this article. All authors collectively designed the methodology, performed the data collection, analyzed the data and wrote the paper with equal responsibility. All authors have read and agreed to the published version of the manuscript.

Conflict of interest: The authors declare no conflict of interest.

\section{References}

Ajuntament de Barcelona (2012).22@ A programme of urban, economic and social transformation. 22@urban Planning Management. Barcelona, Spain: Ajuntament de Barcelona.

Aljohani, K. (2016). Impacts of logistics sprawl on the urban environment and logistics: Taxonomy and review of literature. Journal of Transport Geography. (57) 255-263. DOI: http://doi.org/10.1016/j.jtrangeo.2016.08.009

Àrea Metropolitana de Barcelona (2015). Polígons d'activitat econòmica i productiva a l'AMB. Estudis territorials - direcció de serveis d'urbanisme. Barcelona, Àrea Metropolitana de Barcelona.

Artigues J. ; Caballé F. ; Tatjer M. (2013). El llegat fabril al nucli antic de Barcelona. Cens de fàbriques i edificis actuals de Ciutat Vella amb activitat industrial entre el segle XVIII i principis del XX. Barcelona: MUHB: Documents 6: Ajuntament de Barcelona.

BEST. HutchisonPorts. Recuperado de http://www.best.com.es/

Brites, W. (2016). Grandes proyectos y sus efectos sociales. Tendencias a la sustitución social en espacios urbanos revalorizados. ACE: Architecture, City and Environment, 11(32): 13-32, 2016. DOI: http://doi.org/10.5821/ace.11.32.3964

Bullen P. A. (2007). Adaptive reuse and sustainability of commercial buildings. Facilities 25 (1/2), 20-31.

Busquets J., et al. (2009). Cerdà i la Barcelona del futur: Realitat versus projecte. Barcelona: CCCB Centre de Cultura Contemporània de Barcelona. 
Campos-Sánchez, F.; Abarca-Álvarez, F.; Domingues, A. (2018). Sostenibilidad, planificación y desarrollo urbano. En busca de una integración crítica mediante el estudio de casos recientes. ACE: Architecture, City and Environment, 12 (36): 39-72, DOI: http://dx.doi.org/10.5821/ace.12.36.5145

Capel H. (1996). La rehabilitación y el uso del patrimonio histórico industrial. Doc. Anàl. Geogr. 29.

Cerasoli, M. (2010). Periferias Urbanas Degradadas. Transformación de los Asentamientos y Evolución de Habitar. ¿Cómo Intervenir? ACE: Architecture, City and Environment, 5(14), 45-66, DOI: http://dx.doi.org/10.5821/ace.v5i14.2505

Crainic T.G., Ricciardi N., Storchi G., et al. (2004). Advanced Freight Transportation Systems for Congested Urban Areas. Transportation Research Part C: Emerging Technologies 12, 119-137. DOI: https://doi.org/10.1016/j.trc.2004.07.002

Dantzing G.B. et al. (1973). Compact city: a plan for a livable urban environment. San Francisco: W.H. Freeman.

European Parliament. (2013). Regional Strategies for Industrial Areas. Directorate-general for internal policies. Policy department B: structural and cohesion policies. Recuperado de IP/B/REGI/FWC/2010002/LOT1-C01-SC08

Ewing R. (2008). Characteristics, Causes and Effects of Sprawl: A Literature Review. En: Marzluff J.M. et al. (Eds). Urban Echology. Springer, Boston. DOI: http://dx.doi.org/10.1007/978-0-387-73412-5 34

Font Arellano, A. et al. (2008). Nuevas geografías de la producción y el consumo en la Región Metropolitana de Barcelona. Scripta Nova. XII, 270 (107). Revista electrónica de geografía y ciencias sociales. Recuperado de http://www.ub.edu/geocrit/sn/sn-270/sn-270-107.htm

Fundación BBVA. (2013). Áreas rurales y coberturas del suelo. Documentos de trabajo 2. Madrid, Fundación BBVA. Recuperado de http://www.fbbva.es/TLFU/dat/DT 02 2013\%20 web.pdf

Generalitat de Catalunya. Population 1900-2016. Official Statistics Website of Catalonia. Generalitat de Catalunya. Institut d'estadística de Catalunya. Recuperado de http://www.idescat.cat/pub/?id=aec\&n=245\&lang=en

Guerlain, C; Renault, S; Ferrero, F. (2019). Understanding Construction Logistics in Urban Areas and Lowering Its Environmental Impact: A Focus on Construction Consolidation Centres. Sustainability, 11(21), 6118. DOI: https://doi.org/10.3390/su11216118

Herce M, Miró J. (2012). El soporte infraestructural de la ciudad. Departamento de Infraestructuras del Transporte y Territorio. Barcelona: Edicions UPC, Universidad Politécnica de Cataluña.

Ibàñez i Martí J.J., Burriel Moreno J.A. (2010). Mapa de cubiertas del suelo de Cataluña: características de la tercera edición y relación con SIOSE. Tecnologías de la Información Geográfica: La Información Geográfica al servicio de los ciudadanos. Sevilla, Secretariado de Publicaciones de la Universidad de Sevilla.

Isalgue A, Martinez J.E., Eguren M.L. (2014). Containers Movement Cost Analysis in a Marine Terminal. 6th International Conference on Maritime Transport.

Jacobs J. (1992). The Death and Life of Great American Cities. New York, Vintage-reissue Edition. 
Langston C., Wong F.K.W., Hui E.C.M., Shen L.Y. (2007). Strategic assessment of building adaptive reuse opportunities in Hong Kong. Building and Environment 43 (10). DOI: https://doi.org/10.1016/j.buildenv.2007.10.017

Li Y., Chen X., Tang B-S. et al. (2018). From project to policy: Adaptive reuse and urban industrial land restructuring in Guangzhou City, China. Cities, 82. DOI: 10.1016/j.cities.2018.05.006

Lo Cigno L. (2010). La iluminación natural en la rehabilitación de fábricas antiguas (Master Thesis). Barcelona, Universitat politécnica de Catalunya.

Marmolejo Duarte, C.; Echavarría Ochoa, C.; Biere Arenas, R. (2016). El valor de la centralidad: un análisis para la Barcelona metropolitana. ACE: Architecture, City and Environment, 11(32), 95-112. DOI: https://doi.org/10.5821/ace.11.32.4834

Montgomery C. (2013). Happy City. Transforming our lives through urban design. $1^{\text {st }}$ ed. New York. Farrar Straus and Giroux.

Muñuzuri, J.; Larrañeta J.; \& Onieva L. (2005). Cortés P. Solutions applicable by local administrations for urban logistics improvement. Cities, 22(1), 15-28. DOI: https://doi.org/10.1016/j.cities.2004.10.003

Navratil J.; Krekci T.; Martinat S. ; et al. (2018). Brownfields do not "only live twice": The possibilities for heritage preservation and the enlargement of leisure time activities in Brno, the Czech Republic. Cities, 74, 52-63. DOI: https://doi.org/10.1016/j.cities.2017.11.003

Qiu, R; Xu, W; Zhang, J. (2015). The transformation of urban industrial land use: A quantitative method. Journal of Urban Management, 1. DOI: https://doi.org/10.1016/j.jum.2015.07.001

Regió Metropolitana de Barcelona. (2009). Patrons Urbanístics de les Activitats Econòmiques. Institut d'estudis territorials, Generalitat de Catalunya.

Rodrigue J-P. (2006). The Geography of Transport Systems, 3rd ed. New York: Routledge.

Royal Australian Institute of Architects \& Department of the Environment and Heritage. (2004). Adaptive Reuse. Preserving our past, building our future. Canberra, Australia: Department of Environment and Heritage.

Russo, F; Comi, A. (2020). Investigating the Effects of City Logistics Measures on the Economy of the City. Sustainability 12(4), 1439; DOI: https://doi.org/10.3390/su12041439

Sassi E., Vismara F., Cavadini N.O., Acebillo J. (2009). Industrial areas. A survey, analysis and appraisal of the potential for conversion of disused industrial areas in Ticino. Theoretical and Empirical Researches in Urban Management. Number 2 (11).

Taniguchi E. et al. (1999). Optimal size and location planning of public logistics terminals. Transportation Research Part E: Logistics and Transportation Review, 35. DOI: https://doi.org/10.1016/S1366-5545(99)00009-5

Tatjer M. (2006). La industria en Barcelona (1832-1992). Factores de localización y cambio en las áreas fabriles: del centro histórico a la región metropolitana. Scripta Nova, revista electrónica de geografía y ciencias sociales. X, 218 (46). Recuperado de http://www.ub.edu/geocrit/sn/sn-218-46.htm 
Transport Research Board (1998). The costs of sprawl - Revisited. Transit Cooperative Research Program, Report 39. Washington DC, National Academy Press.

Trubka R., Newman P., Bilsborough D. (2010). The Costs of Urban Sprawl: Infrastructure and Transportation. Environment Design Guide.

UN. Secretary-General. (1987). Report of the World Commission on Environment and Development: Our Common Future. New York, World Commission on Environment and Development.

US Government. (1974). Real State Corporation (RERC). The costs of sprawl: Detailed costs analysis. Washington DC, US Government Printing Office.

Valderrama Barrero C., Serra-Coch G., Alonso-Montolio C., Coch H. (2021). An Urban Strategy for Adaptive Reuse: Learning from Industrial Heritage in Barcelona. En: Littlewood J., Howlett R.J., Jain L.C. (Eds). Sustainability in Energy and Buildings 2020. Smart Innovation, Systems and Technologies, vol. 203. Springer, Singapore.

Verhetsel, A. et al. (2015). Location of logistics companies: a stated preference study to disentangle the impact of accessibility. Journal of Transport Geography 42. DOI: 10.1016/j.jtrangeo.2014.12.002

World Health Organization Urban population growth. Global Health Observatory (GHO) data. Recuperado de: http://www.who.int/gho/urban health/situation trends/urban population growth text/en/

Yung E.H.K., Chan E.H.W. (2015). Implementation challenges to the adaptive reuse of heritage buildings: Towards the goals of sustainable, low carbon cities. Habitat International 36(3), 352-361. DOI: https://doi.org/10.1016/i.habitatint.2011.11.001 